\title{
Intersecciones de lo político: catolicismo, nacionalismo y partidos en Río Cuarto a mediados del siglo $\mathrm{XX}$
}

\author{
Rebeca Camaño Semprini*
}

Fecha de Recepción: 22 de Mayo de 2020

Fecha de Aceptación: 15 de Junio de 2020

DOI: https://doi.org/10.46553/RGES.56.2020.p.36-67

\begin{abstract}
Resumen:
Con el objetivo de evidenciar la porosidad y complejidad de los vínculos y cruces entre lo político y lo religioso, en el presente artículo realizamos la reconstrucción y análisis del devenir entre las décadas del treinta y cincuenta de un segmento político -constituido en la intersección de múltiples ámbitos de participación en la esfera pública- que tuvo una sostenida permanencia en la vida política de Río Cuarto. Proponemos una escala de análisis reducida, desde una perspectiva centrada en las prácticas políticas cotidianas, en un tejido relacional que trascendió la diversidad de los eventuales gobiernos que se sucedieron en el periodo estudiado y que -según entendemos- logró permear en el largo plazo las miradas de lo político.
\end{abstract}

Palabras clave: política; catolicismo; nacionalismo; peronismo

\begin{abstract}
:
With the objective of evidencing the porosity and complexity of the links and crossings between the political and the religious, in the present article we carry out the reconstruction and analysis of the evolution between the thirties and the fifties of a political segment -constituted in the intersection of multiple ambits of participation in the public sphere- that had a sustained permanence in the political life of Rio Cuarto. We propose a reduced scale of analysis, from a perspective centered on daily political practices in a relational fabric that transcended the diversity of the eventual governments that succeeded each other in the period studied and that -we understand- managed to permeate in the long term the gazes of the political.
\end{abstract}

Keywords: politics; Catholicism; nationalism; peronism

\section{Introducción}

Con el retorno a la democracia en 1983, comenzaron a desarrollarse nuevas líneas historiográficas que indagaban acerca del rol de diversos actores que, sin ser partidos políticos, habían influido- o incluso definido en determinados momentos- en el rumbo de la vida política argentina. Entre los estudios emprendidos con la necesidad de comprender el período dictatorial que acababa de cerrarse y, más abarcativamente, las ideas autoritarias que

\footnotetext{
* Centro de Investigaciones Históricas de la Facultad de Ciencias Humanas de la Universidad Nacional de Río Cuarto/Centro de Estudios Avanzados de la Facultad de Ciencias Sociales de la Universidad Nacional de Córdoba/Centro de Investigaciones y Estudios sobre Cultura y Sociedad; Consejo Nacional de Investigaciones Científicas y Técnicas, rebesemprini83@gmail.com
} 
habían arraigado en la cultura política argentina desde 1930, ocuparon un espacio privilegiado aquellos preocupados por las relaciones entre catolicismo, nacionalismo y peronismo. Lejos de diluirse con el transcurrir de los años, este interés fue propagándose en las décadas siguientes y ganando espacio dentro de la historiografía argentina; de manera que, de descripciones homogéneas y simplificadoras fue virando hacia investigaciones que complejizaban cada vez más el panorama. ${ }^{1}$

Diversos autores han dado cuenta de la imprecisión de estos nexos, de la constitución de acercamientos meramente estratégicos y circunstanciales, y de coincidencias ideológicas más profundas. ${ }^{2}$ Así, nacionalismo y fascismo han sido homologados, ${ }^{3}$ se ha subsumido al

'Para una síntesis de esta múltiple producción historiográfica -cuyo abordaje resulta inabarcable dentro de los
límites del presente artículo a cuyos objetivos, por otra parte, escapa- remitimos, entre otros autores a: Ana
María Barletta y María Dolores Béjar, "Nacionalismo, nacionalismos, nacionalistas... iUn debate
historiográfico?" Anuario IEHS, 3 (1988): 357-383; Roberto Di Stefano, "De la teología a la historia: un siglo de
lecturas retrospectivas del catolicismo argentino". Prohistoria 6, 6 (2002): 173-201; Miranda Lida, "El
catolicismo de masas en la década de 1930. Un debate historiográfico", en Sociedad, cristianismo y política.
Tejiendo historias locales, compilado por Cinthya Folquer y Sara Amenta (San Miguel de Tucumán:
Universidad del Norte Santo Tomás de Aquino, 2010): 395-424; Patricia Orbe, "El nacionalismo tradicionalista
argentino en la segunda mitad del siglo XX: recorrida por un territorio en exploración". PolHis 8, (2011): 27-35;
Humberto Cucchetti, "Lecturas e interpretaciones sobre los orígenes del peronismo: ¿nacional-populismo o
adaptación fascista?", Studia Historica. Historia Contemporánea, 30 (2012): 151-171, [http://campus.usal.es/ revistas_trabajo/index.php/0213-2087/article/view/9903]; Facundo Cersósimo, "El tradicionalismo católico argentino: entre las Fuerzas Armadas, la Iglesia católica y los nacionalismos". PolHis 7 , 14(2014): 341-374; Roberto Di Stefano y José Zanca, "Iglesia y catolicismo en Argentina. Medio siglo de historiografía". Anuario de Historia de la Iglesia, 24 (2015): 15-45. [10.15581/007.24.15-45].

${ }^{2}$ Entre otros, y restringiéndonos a aquellos autores que abarcan el período que nos ocupa, podemos señalar: Marysa Navarro Gerassi, Los nacionalistas (Buenos Aires: Jorge Álvarez, 1969); Enrique Zuleta Álvarez, El nacionalismo argentino (Buenos Aires: La Bastilla, 1975); María Inés Barbero y Fernando Devoto, Los nacionalistas (Buenos Aires: CEDAL, 1983); Sandra McGee Deutsch, Counterrevolution in Argentina, 19001932: theargentine Patriotic League (Lincoln: University of Nebraska, 1986); Cristián Buchrucker, Nacionalismo y peronismo. La Argentina en la crisis ideológica mundial (1927-1955) (Buenos Aires: Sudamericana, 1987); Fortunato Mallimaci, El catolicismo integral en la Argentina (1930-1946) (Buenos Aires: Biblos, 1988); David Rock, La Argentina autoritaria. Los nacionalistas, su historia y su influencia en la vida pública (Buenos Aires: Ariel, 1993); Loris, Zanatta, Perón y el mito de la nación católica. Iglesia y Ejército en los orígenes del peronismo (1943-1946) (Buenos Aires: Sudamericana, 1999); Susana Bianchi, Catolicismo y peronismo. Religión y política en la Argentina 1943-1955 (Tandil: Trama/Prometeo/Instituto de Estudios Histórico-Sociales, 2001); Fernando Devoto, Nacionalismo, fascismo y tradicionalismo en la Argentina moderna. Una historia (Buenos Aires: Siglo XXI, 2002); Loris, Zanatta, Del Estado liberal a la Nación católica. Iglesia y Ejército en los orígenes del peronismo.1930-1943 (Bernal: Universidad Nacional de Quilmes (2005 [1996]); María Inés Tato, “¿Alianzas estratégicas o confluencias ideológicas? Conservadores y nacionalistas en la Argentina de los años treinta”, Cuadernos del CLAEH 28, 91 (2005): 119-135; Fortunato Mallimaci, Humberto Cucchetti y Luis Donatello, "Caminos sinuosos: nacionalismo y catolicismo en la Argentina contemporánea", en El altar y el trono. Ensayos sobre el catolicismo político latinoamericano, editado por Francisco Colom y Angel Rivero (Barcelona: Antrophos/Unilibros, 2006), 155-190; Olga Echeverría, Las voces del miedo: los intelectuales autoritarios argentinos en las primeras décadas del siglo XX (Rosario: Prohistoria, 2009); Lila Caimari, Perón y la Iglesia católica. Religión, Estado y sociedad en la Argentina (1943-1955) (Buenos Aires: Emecé, 2010 [1994]); Miranda Lida, "Catolicismo y peronismo: la zona gris". Ecos de la Historia, 6:10-13; Fortunato Mallimaci, El mito de la Argentina laica. Catolicismo, política y Estado (Buenos Aires: Capital Intelectual, 2015); Miranda Lida, Historia del catolicismo en la Argentina entre el siglo XIX y el XX (Buenos Aires: Siglo XXI, 2015).

${ }^{3}$ Fernando Fichelstein, La Argentina fascista. Los orígenes ideológicos de la dictadura (Buenos Aires: Sudamericana, 2008). 
nacionalismo en la explicación de los orígenes y la naturaleza del peronismo, ${ }^{4}$ movimiento que, por otra parte -y según la interpretación propuesta- fue clasificado tanto de expresión vernácula del fascismo como de nacionalismo populista. ${ }^{5}$ Atendiendo a estos múltiples y complejos cruces, también se ha inquirido si el nacionalismo no fue un mero dispositivo discursivo, una retórica de la naciente derecha autoritaria argentina que ocultaba más de lo que evidenciaba sobre sus características y proyectos. ${ }^{6}$ La complejidad abierta por estos variados vínculos se acrecienta ante las dificultades para consensuar una definición ajustada de una tendencia laxa y sin límites precisos, que ha sido identificada alternativamente como exponente del tradicionalismo católico, el nacionalismo o la derecha.

En el análisis de estas, a menudo, ambiguas relaciones adherimos a la advertencia realizada por Mallimaci, Cucchetti y Donatello con respecto a que catolicismo, nacionalismo y peronismo no deben confundirse como un todo relacionado y sin fisura. $^{7}$ Complementariamente, cabe señalar que el panorama se complejiza aún más si atendemos a la pluralidad que habita a los actores analizados, y que -tal como lo han evidenciado sus respectivas historiografías - escapan a una definición singular.

Con diversas perspectivas de análisis, que han focalizado la mirada en una u otra dimensión, un amplio conjunto de investigaciones ha puesto en evidencia las pluralidades insertas dentro del mundo católico argentino, comprendido por un vasto abanico e movimientos con diferentes concepciones, corrientes teológicas, representaciones del mundo, y del rol que los católicos pueden o deben desempeñar en él, pese a los ingentes esfuerzos emprendidos por la institución eclesiástica para uniformar a sus huestes. ${ }^{8}$ Asimismo, entre quienes han estudiado los nacionalismos existe consenso respecto de la recurrente necesidad de apelar a calificativos para alcanzar una mayor precisión en la identificación de grupos y alternativas, de acuerdo con sus propuestas y prácticas, a un punto tal que se ha señalado que esta "preeminencia de la adjetivación"9 pone en evidencia "la incapacidad nominativa del término". ${ }^{10}$ También, el peronismo se ha develado como un abigarrado universo, nutrido de diversas tradiciones y elementos constitutivos, una doctrina de perfil ecléctico ${ }^{11}$ y, quizá por

\footnotetext{
${ }^{4}$ Tal como han señalado Barletta y Béjar, "Nacionalismo, nacionalismos...”, p. 357.

${ }^{5}$ Buchrucker, Nacionalismo y peronismo..., p. 398.

${ }^{6}$ Olga Echeverría, ‘Las cosas por su nombre? Preguntas sobre la propensión a llamar 'nacionalismo' a la derecha argentina de la década de 1920”, en Las derechas en el Cono Sur, Siglo XX. Actas del Taller de discusión, compilado por Ernesto Bohoslavsky (Los Polvorines: Universidad Nacional de General Sarmiento, 2011), pp.1-13.

${ }^{7}$ Mallimaci, Cucchetti y Donatello, “Caminos sinuosos...," p. 169.

${ }^{8}$ Di Stefano, "De la teología a la historia...", p. 197.

${ }^{9}$ Barletta y Béjar, "Nacionalismo, nacionalismos...", p. 357.

${ }^{10}$ Echeverría, “LLas cosas por su nombre?...”, p. 9.

${ }^{11}$ Buchrucker, Nacionalismo y peronismo ..., p. 301.
} 
lo mismo, plagado de conflictos endógenos y pleitos minúsculos, al punto de habilitar que la construcción del partido -que se soñaba de acero y provisto de una disciplina inflexible-fuera caracterizada como un oxímoron. ${ }^{12}$

Nuestra propuesta vuelve a transitar, por lo tanto, uno de los períodos privilegiados por este amplio abanico de estudios. A diferencia del grueso de estos trabajos, nuestra intención no es centrarnos en el análisis de referentes intelectuales, ni dar cuenta de un corpus de ideas más o menos sistematizadas. Tampoco nuestro objeto de estudio desarrolló este tipo de producción, ni las fuentes disponibles han reproducido -salvo excepciones- sus intervenciones públicas, aunque sí dejan traslucir que estas no deben haber pasado de arengas que quizá correspondan más a la agitación callejera que a cavilaciones intelectuales.

Consecuentemente, desde una escala de análisis reducida, nos proponemos reconstruir el devenir de un segmento político -surgido de la intersección de múltiples ámbitos de participación en la esfera pública: partidos políticos, asociaciones católicas, organizaciones de derecha, etc. -, con una permanencia sostenida en la vida política de Río Cuarto. Para ello, nos deslizaremos entre los años treinta y cincuenta por diversos espacios políticos y entramados institucionales, atravesados por fluidas relaciones personales, sociales y hasta familiares que trascendieron los eventuales gobiernos conservadores, radicales, militares y peronistas. Consideramos, en consonancia, que el abordaje de este tejido relacional en diversos escenarios de la política local durante un período relativamente prolongado, nos permitirá captar la porosidad y complejidad de los vínculos e intersecciones entre lo político y lo religioso.

\section{"La Acción Católica es apolítica": cruces entre catolicismo, nacionalismo y radicalismo}

Uno de los rasgos distintivos del catolicismo de los años treinta del siglo XX fue su salida del ámbito de la sacristía y el lanzamiento hacia la conquista de la sociedad toda y, en particular, del espacio político; proceso en el que la Acción Católica tuvo un rol clave. ${ }^{13}$ Fundada en 1931 en Argentina, de acuerdo al modelo de su par italiana, ya desde su organización en Río Cuarto en 1932 se la vinculó con las organizaciones fascistas actuantes

\footnotetext{
${ }^{12}$ Darío Macor y César Tcach, "El oxímoron peronista en las provincias" en La invención del peronismo en el interior del país II, editado por Darío Macor y César Tcach (Santa Fe: Universidad Nacional de Litoral, 2013), pp. 7-13.

${ }^{13}$ Entre otros, coinciden en señalar esta importancia de la Acción Católica, autores como: Zanatta, Del Estado liberal a..., Jessica Blanco, Modernidad conservadora y cultura política. La Acción Católica Argentina (19311941) (Córdoba: Facultad de Filosofía y Humanidades de la Universidad Nacional de Córdoba, 2008), Mallimaci, El mito de la Argentina laica...
} 
en la ciudad. Esta situación se hallaba, por otra parte, estrechamente relacionada con lo que ocurría al interior del radicalismo.

Hacia fines de 1933, la Comisión Directiva del Centro Parroquial de la Acción Católica de Río Cuarto (ACRC) se encontraba en el centro de la escudriñadora mirada de la opinión pública local por su supuesta ligazón con el fascismo. Los rumores comenzaron cuando su vicepresidente primero, Ángel H. Cabral, ${ }^{14}$ renunció a su cargo por considerar que la orientación que le imprimían al organismo no coincidía con "la esencia democrática de la doctrina del Nazareno y con la alta inspiración generadora de ese organismo". ${ }^{15}$ Similares argumentos adujo el tesorero, Miguel Rivarola, quien también renunció a su cargo y se retiró del Centro "acusando a la Acción Católica de erigirse en pedestal de la dictadura hermanando con el partido Fascista". ${ }^{16}$

La prensa local rápidamente se hizo eco de estas acusaciones, por lo que también el presidente de la Comisión Directiva, Carlos Ferraris, recurrió dicho medio para dar su versión de la situación. Bajo el título "La Acción Católica es apolítica", El Pueblo-diario local de tendencia conservadora- difundió los argumentos del presidente del centro parroquial:

El hecho de que yo sea fascista italiano (...) no quiere decir que sea fascista argentino (...) pero aún en el supuesto de que algún día se inscribiese como socio de nuestra institución un fascista criollo, ello jamás podrá significar que la Acción Católica esté adherida a esa tendencia, ya que, con la misma razón, se la podría considerar radical o demócrata, puesto que elementos de dichas filiaciones pertenecen a la Acción Católica, sin que jamás sus ideologías políticas hayan tenido la menor ingerencia (sic) en las actividades de nuestra institución, ni siquiera en las conversaciones entre los asociados a la misma, pues en su actuación católica se sienten fuertemente hermanados, ya que el ideal común que los une está muy por encima de los banderismos políticos. ${ }^{17}$

Pese a esta aclaración, lo cierto es que estas vinculaciones entre dirigentes de Acción Católica y organizaciones del fascismo local no eran para nada ajenas a la vida política

\footnotetext{
${ }^{14}$ Dirigente riocuartense del radicalismo garzonista, es decir, uno de los sectores más tradicionales de la UCR cordobesa. Había tenido además la "fortuna política" de casarse con la hija del líder de esta ala del radicalismo, el Dr. Agustín Garzón Agulla. Ver: César Tcach, Sabattinismo y peronismo. Partidos políticos en Córdoba (1943-1955). (Buenos Aires: Biblos, 2006 [1991]), p. 163.

${ }^{15}$ El Pueblo, 11/11/1933

${ }^{16}$ Archivo del Obispado de Río Cuarto (AORC), Sección Acción Católica (SAC), Asociación de Hombres de Acción Católica (AHAC), Caja 4, Consejo Diocesano.

${ }^{17}$ AORC, SAC, AHAC, Caja 4, Consejo Diocesano.
} 
riocuartense. En 1931 Carlos Vismara -comerciante del lugar, nacido en Italia- había sido electo como intendente municipal con el apoyo de los sectores más tradicionales del radicalismo, nucleados en torno a la figura del médico Felipe Gómez del Junco, y de los que formaba parte Ángel H. Cabral. Sin embargo, poco después, merced al establecimiento del voto directo en las elecciones internas, estas facciones comenzaron a ser desplazadas dentro del partido a favor de una renovación encabezada por el sabattinismo. ${ }^{18}$ Paralelamente, empezaban a circular versiones de que Vismara adscribía al fascismo; rumores que él mismo confirmaría más tarde: "Es verdad que soy fascista, pero fascista italiano, como no es menos verdad que el fascismo italiano nada tiene que ver ni se inmiscuye con el de cualquier otra nación". ${ }^{19}$

A partir de entonces, y de la creciente movilización de los sectores democráticos de la ciudad en contra de lo que identificaban como fuerzas "reaccionarias y traidoras de la verdadera argentinidad", quienes le habían dado su apoyo electoral darían inicio a una campaña de alejamiento y desprestigio de Vismara, en un intento por desvincularse del mote de "colaboracionistas" que les era atribuido. Fue en ese contexto que Ángel Cabral, quien por asociación se hallaba dentro de este núcleo, renunció a su cargo dentro de la Acción Católica riocuartense al acusarla de desvirtuar los principios que debían regirla. Resulta evidente que, en la práctica, la prescindencia política que se le pretendía atribuir estaba lejos de concretarse.

Lo cierto es que esta tormenta se superó airosamente, dado que -aparte de los renunciantes- la Comisión Directiva del Centro se mantuvo hasta la reorganización de Acción Católica bajo la órbita del nuevo obispo, arribado a Río Cuarto en 1935. Así pues, merced a la reforma eclesiástica emprendida un año antes, los organismos ya existentes quedaron desligados de la Junta y Consejos de la flamante Arquidiócesis de Córdoba y pasaron a depender de Río Cuarto. Cuando en 1936, en el marco de un relanzamiento de la Acción Católica en la nueva diócesis, Monseñor Buteler decidió incluir al controvertido Carlos Ferraris como miembro de la primera Junta Diocesana ${ }^{20}$ se dejaba anunciada la aquiescencia que el Obispado mantendría en los años siguientes con sectores identificados con la derecha local.

En efecto, este caso dista de ser aislado: el progresivo estrechamiento de los lazos entre sectores del catolicismo, elementos vinculados a organizaciones de derecha y miembros del ejército tenía como trasfondo el enfrentamiento con el sabattinismo. Aglutinados en torno

\footnotetext{
${ }^{18}$ Rebeca Camaño, "El radicalismo riocuartense: renovación partidaria, conservadores y fascismo en los años treinta", Estudios Sociales, 49 (2015): 11-30.

${ }^{19}$ El Pueblo, 22/03/1934.

${ }^{20}$ Boletín Eclesiástico del Arzobispado de Córdoba, 1936, pp. 373-374.
} 
a la percepción del gobierno provincial como la antesala del comunismo -con cuyo apoyo electoral había contado en las elecciones de 1935- emprendieron una campaña de desprestigio y oposición que se sostenía en diversas estrategias: la emisión de cartas pastorales de las jerarquías eclesiásticas, editoriales en los principales diarios provinciales y nacionales, el accionar de múltiples asociaciones tanto católicas como nacionalistas y gestiones ante las autoridades públicas. ${ }^{21}$

Estas confluencias quedaron evidenciadas en diversas oportunidades. En 1939, desde las páginas de la publicación de la catedral riocuartense La Semana Católica, su cura párroco Pedro Geuna denunció “el bombardeo verbal de los agitadores de Moscú” producido durante las celebraciones del $1^{\circ}$ de mayo, acto cuyos fines -entendía- habían sido desvirtuados "por la propaganda revolucionaria roja". Por una parte, cuestionaba fuertemente la presencia de radicales "en admirable maridaje" como oradores en dicho evento, y reclamaba una desautorización oficial de su participación, "rectificando conceptos, desolidarizándose con la actitud francamente izquierdista, subversiva y revolucionaria". Por otra parte, también se ocupaba de las críticas vertidas por el orador comunista Rufino Gómez, quien en su "jerga anti-nazi-nipo-fasci-franquista" convocaba a la lucha contra los que "califican de 'fascistas', vale decir, a todo el que no esté con ellos", sectores con los que tácitamente se identificaba. ${ }^{22}$

Dos años más tarde, tanto Geuna como Buteler se verían envueltos en un enfrentamiento entre facciones definidas por la prensa local como "democráticos y fascistas". ${ }^{23}$ El episodio comenzó con el ataque que dos sujetos vinculados al fascismo, Hugo Petroff (corresponsal de El Pampero) ${ }^{24}$ y Manuel Luna, infligieron a un transeúnte, Gilberto Zabala, frente a la plaza principal de la ciudad. Cuando el agredido intentó defenderse aprovechando que falló el arma de fuego que aquellos portaban, los provocadores se refugiaron en la iglesia catedral. Ante la denuncia de los numerosos testigos, las autoridades

\footnotetext{
${ }^{21}$ Dada la importancia de Córdoba en el tablero político nacional, este enfrentamiento trascendió las fronteras locales y provinciales, viéndose también plasmado en el Congreso Nacional y en la prensa porteña. Respecto a los esfuerzos en pos de una intervención a la provincia, ver: César Tcach, "Un parto frustrado: la intervención federal a Córdoba (1936-37)", en Territorios de la política argentina. Córdoba y Santa Fe. 1930-1945, editado por Darío Macor y Susana Piazzesi (Santa Fe: Universidad Nacional del Litoral, 2009), pp. 61-86. Sobre las miradas del diario nacionalista Crisol, ver Buchrucker, Nacionalismo y peronismo..., p. 219; de La Fronda, publicación representativa del conservadorismo, ver Tato, “¿Alianzas estratégicas...”, p. 132; en la católica Criterio, ver Devoto, Nacionalismo..., p. 222.

${ }^{22}$ La Semana Católica, 07/05/1939.

${ }^{23}$ Los episodios de enfrentamientos callejeros entre elementos fascistas y democráticos fueron comunes en la época. Para una síntesis de algunos de ellos en el espacio riocuartense, remitimos a Rebeca Camaño Semprini, "Ecos de la Guerra Civil Española. La derecha nacionalista y los frentes antifascistas en los espacios locales argentinos". Diacronie Studi di Storia Contemporanea, 17 (2014):1-15.

${ }^{24}$ El vespertino El Pampero fue publicado entre 1939 y 1944, bajo la dirección de Enrique Osés y contaba con el financiamiento de la Embajada de Alemania en Argentina. Ver: María Inés Tato, "El ejemplo alemán. La prensa nacionalista y el Tercer Reich", Revista Escuela de Historia, 6 (2007): 34-60.
} 
policiales se presentaron a la casa parroquial y solicitaron el permiso para proceder a la detención de los atacantes, pero les fue denegado. En estas circunstancias, se dirigieron al Obispo, quien avaló el proceder de su subordinado y -tras la intervención del juez de instrucción- convino en entregarlos al día siguiente, lo cual hizo en compañía de Horacio Turdera y Guillermo Torres Fotheringham, referentes máximos del fascismo riocuartense. ${ }^{25}$

El diario cordobés $\mathrm{La}$ Voz del Interior ponía de manifiesto las tramas entre estos sectores y la Iglesia riocuartense al calificar a Petroff como un individuo "que tiene antecedentes policiales y que es sindicado en todo Río Cuarto, como elemento pendenciero, pese a que alterna sus actividades totalitarias, con salmos en las iglesias, donde oficia de cantor a sueldo", al tiempo que criticaba duramente la actitud asumida por Buteler, a quien consideraba como "abiertamente defensor del nazismo". ${ }^{26}$ Por otra parte, se ligaba lo sucedido, a la presencia del General Juan Bautista Molina en la localidad, militar de ultraderecha que por entonces ocupaba un puesto importante dentro del nacionalismo $\operatorname{argentino~}^{27}$ y que -según las versiones circulantes- contaba con el franco apoyo de Geuna.

"Los muchachos del Monseñor" -como los denominaba el diario radical-quedaron en libertad al día siguiente por falta de méritos, sin embargo, el episodio tendría fuertes resonancias. Buteler envió un telegrama al gobierno provincial en el que reclamaba garantías para las personas e instituciones católicas y reafirmaba las vinculaciones de los elementos fascistas con la Iglesia riocuartense: "Estos procedimientos han invadido ya domicilios particulares, habiéndose dado el caso de asaltar al joven Hugo Petroff en la casa parroquial de la Catedral. Yo pido, Excelencia, garantías para las víctimas mencionadas (...) cuya conducta intachable me es conocida por tratarse de personas que en diversas formas actúan en la vida religiosa de la ciudad". ${ }^{28}$

El foco de las críticas se dirigía a la organización antifascista y aliadófila Acción Argentina, ${ }^{29}$ cuya Junta Ejecutiva local -que reunía en su seno a ciudadanos independientes y dirigentes radicales, socialistas, demócratas y comunistas- emitió un extenso comunicado en el que se acusaba a Geuna de no ocultar "sus simpatías fascistas" y se cuestionaba a Buteler

\footnotetext{
${ }^{25}$ Ambos dirigentes se vieron involucrados en numerosos episodios violentos durante los años treinta.

${ }^{26}$ La Voz del Interior, 29-30/10/1941.

${ }^{27}$ Estrechamente vinculado al, para entonces, fallecido ex presidente Uriburu, de quien había sido operador político desde fines de los años veinte y secretario durante su gobierno. Formó parte del cuerpo de oficiales en actividad que brindó entrenamiento a los miembros de la Legión Cívica creada en 1931. Desde mediados de la década del treinta e inicios de los cuarenta, encabezaría múltiples connatos golpistas e intentos de unificación del nacionalismo. Cfr: Buchrucker, Nacionalismo y peronismo..., pp. 118, 146, 208 у 212; y Devoto, Nacionalismo..., pp. 247 y 270.

${ }^{28}$ Boletín Eclesiástico del Arzobispado de Córdoba, 1941, p. 542.

${ }^{29}$ Sobre los orígenes, propósitos y expansión geográfica de esta asociación en el país, remitimos a Andrés Bisso, Acción Argentina. Un antifascismo nacional en tiempos de guerra mundial, (Buenos Aires: Prometeo, 2005).
} 
por "salir en defensa, de modo apasionado y desmedido, de individuos que proclamaban en todos los tonos su militancia nazista". En este sentido, se preguntaba si al hablar de "nuestros perseguidores" Buteler olvidaba expresar en qué consistían "las persecuciones de que se considera víctima y cuáles son las instituciones católicas que han sido atacadas", o peor aún, "su exaltada petición de garantías lo [llevaba] a identificarse, lo que sería penoso, con los provocadores del nazismo conocidos públicamente". ${ }^{30}$

De inmediato, Acción Católica salió en defensa de las autoridades eclesiásticas, a través de sendas solicitadas que eran publicadas en la prensa local y provincial. ${ }^{31}$ Sin embargo, su rol no se limitó a esta defensa pública, sino que además uno de sus miembros más activos en la esfera riocuartense, Tristán Castellano, fue quien asumió la representación de los acusados ante la justicia. En su carácter de abogado defensor, envió telegramas al Ministerio del Interior y al Poder Ejecutivo cordobés, denunciando "atropellos cometidos en contra de las personas de mis defendidos por elementos amparados por la policía local". Simultáneamente, "ante la parcialidad que demuestra la policía en la reiteración de estos hechos" solicitaba "se les dispensen garantías en forma especial y con carácter urgente con el objeto de evitar sucesos de consecuencias más graves". ${ }^{32}$

Cabe remarcar que -como ya mencionamos- estos enfrentamientos tenían como trasfondo un escenario político marcado por la ofensiva contra el gobierno provincial sabattinista, en el que la Acción Católica adquirió un rol particularmente relevante en la defensa tanto de la Iglesia como del orden social y político por ella propuesto. Si además, tenemos en cuenta que Córdoba fue la única provincia argentina donde los grupos del nacionalismo vinculados a organizaciones de derecha fueron efectivamente reprimidos, ${ }^{33}$ no resulta extraño el beneplácito con que se recibiría el golpe de Estado de 1943 por amplios sectores, para quienes el reemplazo de las autoridades provinciales significaba una posibilidad de volver a "foja cero" en múltiples materias.

\section{Nacionalistas, católicos y políticos en tiempos de militares}

Si la Iglesia fue quien vio con mayor certeza el rumbo de los acontecimientos en junio de 1943, y Buteler fue pionero al explicitar temprana y abiertamente su apoyo al golpe de Estado, frente a la prudencia de los partidos políticos, los sindicatos y la opinión pública en

\footnotetext{
${ }^{30}$ La Voz del Interior, 01/11/1941.

${ }^{31}$ Tribuna, 31/10/1941; El Pueblo, 31/10/1941; Los Principios, 01/11/1941; La Semana Católica, 02/11/1941.

${ }^{32}$ Los Principios, 02/11/1941.

${ }^{33}$ César Tcach, "Entre la tradición conservadora y la tentación fascista: la derecha cordobesa contra Amadeo Sabattini", XII Jornadas Interescuelas/Departamentos de Historia (San Miguel de Tucumán: Universidad Nacional de Tucumán, 2007).
} 
general, ${ }^{34}$ la Acción Católica de Río Cuarto (ACRC) advirtió aun antes la confluencia de objetivos con el gobierno militar. En efecto, en la reunión del 8 de junio, es decir a solo cuatro días de la destitución de Castillo, el presidente del Centro de la Asociación de Hombres de la Acción Católica de la catedral, Jorge Olivera, manifestó que era "deber de los católicos apoyar al nuevo gobierno que se apresta devolver a Cristo a las escuelas y combatir el comunismo". 35

Consecuentemente, durante los gobiernos de la autodenominada Revolución de Junio, la ACRC actuaría como instancia articuladora de múltiples dimensiones en las que se observa una simbiosis entre el poder militar y el eclesiástico. En primer lugar, fue la encargada de "generar conciencia" sobre la importancia de la enseñanza religiosa en las escuelas. A tal efecto, las directivas diocesanas instaban a convencer a los padres de "su obligación de vigilar" que sus hijos no abandonaran las clases de religión cuando éstas comenzaran a dictarse, valiéndose para ello tanto de conversaciones individuales como de la prensa local. ${ }^{36}$

En segundo lugar, a través de su Secretariado de Moralidad, procuró bregar por el cumplimiento de los preceptos morales dictados por el catolicismo y entonces adoptados como política estatal. ${ }^{37}$ Tradicionalmente, desde los diversos ámbitos católicos se había buscado influir sobre las prácticas sociales tratando de encauzarlas en los marcos de la moral católica. Lo novedoso fue que, en aquella ocasión, desde la municipalidad se los convocara para colaborar en las campañas de moralidad, emprendidas conjuntamente con la Jefatura Política departamental. Desde julio de 1943 se definirían diversas "medidas moralizadoras" y de "saneamiento social", encaminadas en primera instancia a regular los bailes populares organizados en Río Cuarto -para lo cual se cerraron locales y se emitieron disposiciones para regular los festejos de Carnaval de modo tal que se garantizara el orden y la moral-, y a controlar el contenido de los espectáculos cinematográficos, en particular los destinados al público infantil. ${ }^{38}$ Resulta fundamental observar que este accionar no se limitó a su expresión pública sino que avanzó sobre prácticas privadas. En esta dirección, en agosto de 1943 se

\footnotetext{
${ }^{34}$ Cfr: Zanatta, Perón y el mito..., p.15 y ss.; César Tcach, "Entre la benevolencia y la sospecha: los actores políticos de Córdoba ante el golpe de 1943 y el fin de la experiencia sabattinista", Avances del Cesor 12, 13 (2015): 35-48; Rebeca Camaño Semprini, "De 'reinado sabio' a 'tiranía': el peronismo desde la mirada de Monseñor Leopoldo Buteler (Río Cuarto, 1945-1955), Coordenadas. Revista de Historia Local y Regional 7, 1 (2020): 61-84.

${ }^{35}$ AOC, SAC, AHAC, Caja 7, Catedral, Libro de Actas, Acta No 335, p. 223.

${ }^{36}$ AORC, SAC, AHAC, Caja 4, Consejo Diocesano, Circular enviada a los Centros de la AHAC, 29/02/1944.

${ }^{37}$ Rebeca Camaño Semprini, "Laicos y políticos: la Acción Católica en la vida partidaria riocuartense (19361946)", Revista de Historia Americana y Argentina, 53 (2018): 67-97.

${ }^{38}$ Los Principios, 25/07/1943 y 16/01/1944; El Pueblo, 20/07/1943, 25/07/1943, 30/07/1943 y 05/09/1943.
} 
dispuso el control policial en los zaguanes de las casas céntricas, donde presumiblemente se encontraban parejas de novios. ${ }^{39}$

Es pertinente señalar que estas acciones se vieron precedidas por una estrategia de acercamiento y cooptación de las nuevas autoridades, y en especial, de un ala militar con atención a la presencia en Río Cuarto de la IV Región Militar. Dos casos resultan paradigmáticos en ese sentido: el coronel José Etchichury y el ingeniero Lucio Tórres Ordóñez. El primero, encargado de la organización de reservistas en la ciudad, mientras que el segundo asumió la Jefatura Política desde julio de 1943.

Ambos contaron con la preferencia de la jerarquía eclesiástica. Esto se hizo particularmente evidente al momento de seleccionar quiénes integrarían los órganos diocesanos de la ACRC. En efecto, en 1941, Etchichurry había sido oficializado como socio del centro parroquial de la catedral, y tres años después sería nombrado presidente de la Junta Diocesana. Para entonces, también dirigía la Asociación de Reservistas Patria. ${ }^{40}$ Impulsada bajo el influjo militar, con la "superior finalidad de despertar, mantener y acrecentar el sentimiento patrio y los valores espirituales de la población", ${ }^{41}$ esta asociación era promocionada en el seno de las reuniones de la ACRC, en las que el coronel incluso repartía formularios para quienes quisieran sumarse. ${ }^{42} \mathrm{Al}$ respecto, cabe suponer que logró cosechar prominentes adhesiones, puesto que en su Comisión Directiva se incluyeron como vocales los nombres de los miembros de la dirigencia de la ACRC, a saber, Pedro González y Luis Domínguez. El análisis de los libros de actas nos permite afirmar que episodios de este tipo en los que se promocionaban organizaciones ajenas a la Iglesia- no eran comunes en estas instancias, por tanto, consideramos que constituyen muestras cabales de los estrechos vínculos que se venían gestando entre la ACRC y las autoridades militares locales.

En palabras de su presidente, la Asociación de Reservistas Patria se trataba de un organismo encargado de la "movilización moral y patriótica", cuyo origen se enraizaba en el convencimiento de las autoridades nacionales de que los valores morales eran determinantes en la aptitud de los hombres para la paz y para la guerra. En consonancia, se buscaba afianzar "la defensa del hogar, de la sociedad y de la patria". ${ }^{43}$ Entre 1943 y 1946 esta entidad adquirió gran presencia pública, hasta convertirse en uno de los atractivos principales de los actos

\footnotetext{
${ }^{39}$ El Pueblo, 27/08/1943.

${ }^{40}$ Organizaciones de este tipo estaban compuestas por argentinos mayores de 21 años, sin distinción de credos, que voluntariamente desearan formar parte de ellas. Su dirección y administración eran confiadas por las autoridades militares a personas elegidas entre "los vecinos más caracterizados y de antecedentes morales intachables de cada población". El Pueblo, 26/10/1943.

${ }^{41}$ AORC, SAC, AHAC, Caja 7, Catedral, Libro de Actas, Acta No343, p. 231; El Pueblo, 26/10/1943.

${ }^{42}$ AORC, SAC, AHAC, Caja 7, Catedral, Libro de Actas, Acta Nº356, p. 244.

${ }^{43}$ El Pueblo, 09/11/1943.
} 
patrios y celebraciones cívicas, lo que les valió reiteradas felicitaciones por "la gallardía, disciplina y entusiasmo puestos en evidencia". ${ }^{4}$

El caso de Torres Ordóñez resulta incluso más elocuente. Su ascenso dentro de las filas de la ACRC fue sumamente acelerado. A pocos días de haber asumido como jefe político del departamento de Río Cuarto, asistió por primera vez a las reuniones del centro parroquial de la catedral. Apenas un año después, ya sería incorporado al Consejo Diocesano, y luego, designado su presidente. Cabe mencionar que esta elección recaía exclusivamente en el obispo, por lo que su nombramiento no era azaroso.

La confluencia entre católicos y militares también se manifestaba en una común matriz ideológica, ordenada en torno al mito de la argentinidad, en el que -bajo un manto de apoliticismo o metapoliticismo- el credo católico era elevado a elemento cardinal de la identidad nacional y, por ende, de la legitimidad política e, incluso, del principio de ciudadanía. ${ }^{45}$ Así lo manifestó el propio Torres Ordóñez al asumir la Jefatura Política: "En este nuevo orden han desaparecido los partidos políticos, quedando solamente el azul y blanco de nuestra bandera que a todos nos cobija y a todos nos une, argentinos y extranjeros (...) comprometo mi conciencia de católico para proceder (...) y pido a Dios que ilumine el camino, que nos proteja y guíe". ${ }^{46}$

Esta retórica prescindente de la política partidaria se sostuvo mientras las dependencias departamentales y municipales estuvieron en manos militares, situación que se vio modificada a partir de mediados de 1945. Desde entonces, comenzaría un deliberado recambio de autoridades, en favor de civiles vinculados al radicalismo antisabattinista. ${ }^{47}$ En el ámbito riocuartense, los cargos públicos recayeron en figuras provenientes del garzonismo, sector que -como vimos en el apartado anterior-durante los años treinta había despertado sospechas de estar vinculado al fascismo local. Entre sus filas, se destacaba Felipe Gómez del Junco, designado en agosto comisionado municipal. Los lazos entre este dirigente y el Obispado riocuartense hundían sus raíces en su inserción dentro de instituciones locales cercanas a la Iglesia, pero se vieron profundizados en estos meses de 1945, al punto que, en el lapso que va de octubre a febrero de 1946, tanto las jerarquías eclesiásticas como las

\footnotetext{
${ }^{44}$ Los Principios, 16/07/1944.

${ }^{45}$ Al respecto remitimos a Zanatta, Perón y el mito..., p. 147.

${ }^{46}$ El Pueblo, 20/07/1943.

47 Rebeca Camaño Semprini, Peronismo y poder municipal. De los orígenes al gobierno en Río Cuarto (Córdoba, 1943-1955) (Rosario: Prohistoria, 2014): p. 38.
} 
organizaciones laicales locales y sectores afines identificados con el nacionalismo, tendrían participación en la campaña electoral a favor de la fórmula peronista. ${ }^{48}$

Así, además de la repartición de tres mil folletos, las distintas ramas de la ACRC se distribuirían las tareas de propaganda personalizada. A los miembros de la Asociación de Hombres se les encomendó un listado de profesionales universitarios a quienes debían persuadir; mientras que las mujeres tenían que hacer lo propio con las "madres de familia"; y los jóvenes, con los profesores de enseñanza secundaria del Colegio Nacional y la Escuela Normal. La Federación de Maestros y Profesores Católicos y el Círculo Católico de Obreros asumieron una tarea similar entre maestros de enseñanza primaria y dirigentes de asociaciones obreras y empleados de comercio, respectivamente. Se recurrió también a las conexiones de la ACRC con referentes de la política riocuartense para entablar diálogos con representantes de los distintos partidos locales. ${ }^{49}$ Por su parte, la Agrupación de Profesionales Universitarios Democráticos repudió públicamente "la posición antidemocrática de los dirigentes nazinacionalistas Dres. Horacio Turdera, Luis G. Fotheringham y Tristán Castellano cuyas actividades han contribuido y contribuyen a la nefasta labor del naziperonismo". 50 Diversos representantes de la prensa opositora al gobierno militar denunciaban la participación explícita tanto del secretario del Obispado y párroco de la catedral, Pedro Geuna, como del propio Buteler, quien había llegado a decir: “quien no vote por Perón en los próximos comicios comete pecado mortal". 51

\section{"Pueblo, cruz y espada": religión y política en los años peronistas}

Las recompensas no tardaron en llegar. A la política de beneficios económicos dispensados a la Iglesia cordobesa durante la gobernación peronista de Argentino Auchter, ${ }^{52}$ debemos sumar los importantes incentivos concedidos puntualmente al Obispado riocuartense a través de los legisladores nacionales que provenían del peronismo departamental. Especialmente ilustrativa, al respecto, es la labor parlamentaria del diputado nacional Amado Curchod, quien reunía entre sus principales iniciativas un proyecto de ley de crédito para obras de construcción en el Seminario Diocesano de Río Cuarto y en su casa de campo en Las Peñas, así como subsidios para la parroquia de Moldes, el Instituto Incorporado Cristo Rey de

\footnotetext{
${ }^{48}$ Para un análisis pormenorizado de esta participación remitimos a Camaño Semprini, "De 'reinado sabio'...”, pp. 63-66.

${ }^{49}$ AOCR, SAC, AHAC, Caja 7, Catedral, Libro de Actas, Actas 393-344, pp. 284-296.

${ }^{50}$ Solicitada publicada en la prensa local y reproducida en Felipe Gómez del Junco, El Perón que yo conocí (Buenos Aires: edición del autor, 1982): p. 52.

${ }^{51}$ Las denuncias fueron publicadas por el diario El Pueblo, 27/02/1946; Córdoba, 14/02/1946 y La Opinión, 13/02/1946. Es en esta última nota en que se reproduce la frase atribuida a Buteler.

52 Tcach, Sabattinismo y peronismo..., p. 96.
} 
Río Cuarto y el propio Obispado. ${ }^{53}$ De manera concomitante, funcionarios vinculados a Gómez del Junco le tramitaban ante la Dirección General de Municipalidades exenciones impositivas para las refacciones que realizaba en sus parroquias, y le otorgaban a la ACRC subsidios del Estado municipal para el desarrollo de sus actividades, al tiempo que se le concedía el Salón Blanco de su palacio de gobierno para que se celebraran conferencias durante sus asambleas. ${ }^{54}$ En contrapartida, era frecuente la presencia de las jerarquías eclesiásticas en eventos que -aunque oficiales- tenían un claro tinte partidario, como las inauguraciones de obras o los festejos de aniversarios.

En el análisis de dichos tratos entre sectores del catolicismo local y un ala del peronismo departamental debemos tener en cuenta que las elecciones de 1946 no incluyeron a las municipalidades, pues en la provincia de Córdoba, durante gran parte del período peronista quedaron a cargo del gobierno de comisionados, cuyo nombramiento provenía de las autoridades provinciales. ${ }^{55}$ Esta ausencia de comicios municipales implicó que las disputas, alianzas y posicionamientos, al interior del partido, tanto vertical como horizontalmente, tuvieran una repercusión prácticamente inmediata en la estructura de los poderes públicos locales. Puestos como el de comisionado municipal y jefe político adquirieron así, una fuerte carga de $\operatorname{status}^{56}$ por su estrecha dependencia de las cambiantes relaciones de fuerza existentes en el seno del gobierno; y consecuentemente, se convirtieron en botines disputados por las distintas fracciones del peronismo local. ${ }^{57}$

Fue en ese marco que -el ya mencionado abogado dirigente de la ACRC-, Tristán Castellano se desempeñó como asesor letrado de la Municipalidad durante la gestión del gomezjunquista Federico Pereyra Zamudio. Éste, por otra parte, en la IV Asamblea Diocesana de las jóvenes de la ACRC, celebrada en mayo de 1947, expresó: "Esta ciudad, que un siglo atrás fue la avanzada de la civilización cristiana para contener la avalancha del indio salvaje, más con la fe y con la cruz, que con la espada, hoy es centro de gran progreso en lo intelectual, en el comercio, en la industria, en la ganadería y en la agricultura; y por sobre todo eso es sede de una Diócesis de la Iglesia Católica". ${ }^{58}$

\footnotetext{
${ }^{53}$ Honorable Cámara de Diputados de la Nación, Dirección de Información Parlamentaria, Labor parlamentaria del diputado nacional Amado Curchod.

${ }^{54}$ Archivo Histórico Municipal de Río Cuarto (AHMRC), Departamento Ejecutivo, 1947, Legajo Intendente, Correspondencia remitida.

${ }^{55}$ Recién en 1951 se convocó a elecciones en un exiguo número de ciudades, entre las que se encontraba Río Cuarto.

${ }^{56}$ En términos de Angelo Panebianco, Modelos de partido. Organización y poder en los partidos políticos (Madrid: Alianza, 1990 [1982]), p. 40.

${ }^{57}$ Camaño Semprini, Peronismo y poder municipal..., pp. 58-70.

${ }^{58}$ La Voz de Río Cuarto, 03/05/1947.
} 
A las claras, no era meramente una disertación protocolar sino una lectura del pasado y el presente riocuartense y nacional, en la que se le asignaba un rol central a la Iglesia como elemento civilizatorio y un puesto de avanzada a la ciudad en la "Campaña del Desierto" del siglo XIX y en la construcción de una Nación católica en el presente. Pero esa Nación debía ser también peronista, y ello queda explícito en el cierre de las jornadas, cuando el senador nacional Felipe Gómez del Junco afirmó que era "menester que los peronistas sigamos como hasta ahora unidos en un solo abrazo, en esa trilogía que es el pueblo, la cruz y la espada". 59

Como colofón de esta articulación entre dirigentes peronistas y Obispado, en la que confluían también vínculos con exponentes del nacionalismo riocuartense y miembros de la Acción Católica, en octubre de 1947 monseñor Buteler viajó a Buenos Aires junto al comisionado municipal Federico Pereyra Zamudio, el presidente de la Cámara Civil y Comercial, Roberto Torres Vélez y Luis Guillermo Torres Fotheringham, con el cometido de invitar al presidente Perón a los actos celebratorios del $150^{\circ}$ aniversario de la fundación de Río Cuarto. Las gestiones resultaron exitosas y consiguieron la promesa de la visita del matrimonio presidencial, aunque luego su presencia se vería frustrada.

Uno de los primeros problemas se suscitó cuando la Comisión de Festejos Populares que venía desarrollando las tareas pertinentes desde meses atrás fue relegada a los cargos de vocalía y suplantada por otra, integrada por miembros destacados de la sociedad riocuartenese, a la cabeza de los cuales se encontraba Buteler. Esta nueva composición no dejaba lugar a dudas sobre la simbiosis entre sectores representativos del catolicismo local, un ala del peronismo y los jefes militares, ni respecto de sus lazos con organizaciones nacionalistas. Entre los presidentes honorarios se encontraban el Comandante de la IV Región Militar, el coronel Francisco López Ramírez, el senador Gómez del Junco, el diputado Amado Curchod y el dirigente católico Etchichurry. Como secretario se desempeñaba Tristán Castellano, y entre los vocales honorarios se incluían altos cargos departamentales de la administración pública, el Ejército y la Justicia. Sin embargo, el nombre que más reticencias despertó en la opinión pública fue el de Luis Guillermo Torres Fotheringham, quien revestía la función de nada menos que presidente ejecutivo. ${ }^{60}$

Se criticó, además, que el sentido de la fecha parecía haber cambiado: en lugar de conmemorarse el $150^{\circ}$ aniversario de la ciudad se celebraría la llegada de Perón. En respuesta a estos rumores, Torres Fotheringham y Castellano se apresuraron a emitir un comunicado de prensa en el que aclaraban que sus funciones se limitaban a la preparación estrictamente

\footnotetext{
${ }^{59}$ La Voz de Río Cuarto, 04/05/1947.

${ }^{60}$ El Pueblo, 21/10/1947.
} 
protocolar del programa oficial de los festejos, mientras que "las concentraciones populares y similares, deben ser preparadas por los legisladores nacionales y organizaciones gremiales correspondientes". 61

En efecto, dos sectores enfrentados dentro del peronismo, liderados por el senador nacional Gómez del Junco y el ex senador provincial Isidoro Varea respectivamente, emitieron cada uno por su lado, sendas invitaciones en los diarios locales, llamando a dirigentes gremiales, mujeres y simpatizantes en general a participar de la bienvenida a Perón. Por cierto, para comprender estas disidencias debemos remitirnos al conflicto desatado entre ellos a comienzos de 1947, cuando Varea fue designado como secretario general de la Junta Provincial del Partido Peronista, y luego de su triunfo en las internas celebradas en septiembre en ocasión de elegir convencionales nacionales para el Congreso General Constituyente del partido, se vio mejor posicionado que el candidato sostenido por Gómez del Junco, Marcos Giuliano. Esta victoria lo había ubicado, además, como posible candidato en las futuras elecciones legislativas, a celebrarse en marzo de $1948 .^{62}$

En síntesis, los festejos por el aniversario de la ciudad y la visita de Perón no podían proyectarse en un escenario de mayor enfrentamiento al interior del peronismo. Para ilustrarlo, basta decir que se habían tenido que suspender las conmemoraciones del "Día de la Lealtad" por las desavenencias entre los dirigentes riocuartenses. ${ }^{63}$ Fue en este contexto que, a fines de octubre, comenzó una competencia entre Gómez del Junco y Varea que buscaba definir quién de ellos estaba legitimado para convocar a la población en nombre del partido. Esta pugna adquirió carácter público por mediación de la prensa local, donde ambos emitían solicitadas en las que se desautorizaban mutuamente y se autoerigían en los "auténticos representantes del peronismo" en el distrito. ${ }^{64}$ En este clima, acrecentó la percepción de que el aniversario se venía limitando "a una jornada de carácter político partidario exclusivamente" ${ }^{95}$; asimismo, llevó a que comenzara a especularse con la posibilidad de que Perón suspendiera su visita a Río Cuarto, vaticinio que finalmente se cumpliría.

Un punto de inflexión que definió este desenlace fue la conformación de dos comisiones femeninas abocadas a darle la bienvenida a Evita a la ciudad. Una de ellas, sostenida por Varea, solicitó permiso al comisionado Pereyra Zamudio para desarrollar sus

\footnotetext{
61 Justicia, 27/10/1947.

${ }^{62}$ Camaño Semprini, Peronismo y poder municipal... pp. 61-66.

${ }^{63}$ Rebeca Camaño, El uso público del tiempo libre de los trabajadores riocuartenses (1945-1955). Trabajo Final de Licenciatura en Historia (Río Cuarto: Departamento de Historia, Facultad de Ciencias Humanas de la Universidad Nacional de Río Cuarto, 2011).

${ }^{64}$ El Pueblo, 24/10/1947; 25/10/1947; Justicia, 24/10/1947; 27/10/1947.

${ }^{65}$ El Pueblo, 26/10/1948.
} 
reuniones en el salón de actos del Palacio Municipal. Dado que el funcionario probablemente por responder a Gómez del Junco- se negó a tal demanda, la presidenta de la comisión optó por dirigirse al interventor federal de Córdoba, Aristóbulo Vargas Belmonte, cuyas relaciones con el senador nacional distaban de ser cordiales, al tiempo que mantenía un trato fluido con Varea.

Dado que el gobierno provincial presionó al comisionado para que brindara aquella autorización, Pereyra Zamudio renunció a su cargo luego de acatar la orden. En solidaridad, Tristán Castellano abandonó su puesto como asesor letrado de la Municipalidad y, conjuntamente con el resto de la comisión de festejos, presentó su renuncia. Quedaban desbaratados así los amplios preparativos que venían desarrollándose para la llegada de Perón a la ciudad. Poco después se haría manifiesta su decisión de no hacerse presente en los festejos.

Luego de la renuncia de Pereyra Zamudio, el puesto de comisionado municipal fue ocupado por Alfredo Nolasco Ferreyra, quien simultáneamente estaba a cargo de la Inspección General de Municipalidades de la provincia. Esto produjo un reacomodamiento al interior del peronismo que tuvo notorias consecuencias para la vida política riocuartense, pues quienes hasta entonces habían detentado el poder departamental, funcionarios que respondían a Gómez del Junco y se hallaban vinculados a sectores del catolicismo y el nacionalismo local, se vieron desplazados de sus cargos.

A partir de entonces, comenzaba una fuerte oposición al nuevo titular del Ejecutivo municipal, particularmente a través de las páginas de La Voz de Río Cuarto, diario nacido en septiembre de 1946 como órgano difusor de las ideas oficialistas. Con la dirección del entonces senador provincial Isidoro Varea, contaba entre sus socios fundadores con influyentes figuras del peronismo riocuartense como Gómez del Junco, Curchod, Lobos Castellanos y Pereyra Zamudio. Este último, a partir de 1947 sustituiría a Varea como director del diario, como consecuencia del enfrentamiento con Gómez del Junco, y sería el encargado de llevar a cabo la citada campaña en contra de su sucesor en el palacio municipal. ${ }^{66}$

Más tarde, en julio de 1948 el diario publicó una serie de artículos en los que se denunciaba a Nolasco Ferreyra por malversación de fondos. ${ }^{67}$ En ellos se hacía referencia a la compra de motoniveladoras y de automóviles por parte de la municipalidad a cambio de una comisión, como también, a la venta irregular de un automóvil de la asistencia pública al

\footnotetext{
${ }^{66}$ Camaño Semprini, Peronismo y poder municipal ..., p. 88.

${ }^{67}$ Esta campaña tuvo lugar enmarcada por una serie de enfrentamientos entre las jerarquías diocesanas y el gobierno municipal. Al respecto: Camaño Semprini, “De 'reinado sabio'...”, pp. 69-75.
} 
dirigente peronista Oscar Baldassarre. Este dirigente era quien encabezaba en el departamento el proyecto centralizador al interior del partido, impulsado por las autoridades tanto gubernamentales como partidarias; vale decir, proyecto al que se oponía el sector gomezjunquista y otros referentes del peronismo de la primera hora de Río Cuarto. ${ }^{68}$ Finalmente, se denunciaba el uso indebido de una suma que rondaba entre los treinta y cuarenta mil pesos que debería haberse destinado la construcción de un cementerio en el este del barrio Alberdi. Entre los autores de estas denuncias, que finalmente la justicia desestimaría, se identificó a Tristán Castellano. El comisionado municipal, entonces, solicitó que, conjuntamente con Pereyra Zamudio, fuera juzgado por delito de imprenta, e inició una querella en contra de La Voz de Río Cuarto por calumnias e injurias. ${ }^{69}$

Tiempo después, los responsabilizó de haber confundido intencionalmente a la población riocuartense al transmitir erróneamente la suspensión de una misa en acción de gracias debido a un intento de atentado contra la vida del presidente y su esposa. En esta maniobra el comisionado “veía la mano secreta de la camarilla 'La Voz de Río Cuarto' de la cual formaba parte el señor Cura" y, en particular, hacía responsable a Tristán Castellano. Finalmente, la misa se pudo celebrar, y a ella asistió un vasto público y altos dirigentes del peronismo, militares y autoridades civiles. Una ausencia fue marcada por Nolasco Ferreyra: Gómez del Junco no estuvo presente y sí concurrió, en cambio, a la misa ordinaria de todos los domingos en la catedral, celebrada por Geuna. ${ }^{70}$

En aquella oportunidad, el comisionado se dirigió a Buteler a fin de responsabilizarlo por utilizar "la influencia de su alta investidura" para impedir la realización de la misa y, en tal sentido, solicitaba las explicaciones que consideraba pertinentes. $^{71}$ Luego de un intercambio de notas y declaraciones públicas, el Obispado prohibió la participación de eclesiásticos en los actos programados por Nolasco Ferreyra. ${ }^{72}$ Poco después, éste abandonaría su lugar al frente del gobierno municipal y sería reemplazado por Teófilo Pío Bildósola. Sugestivamente, semanas más tarde, en un homenaje que brindara la Acción Católica de Río Cuarto y en el que se hallaba presente el nuevo comisionado, Buteler advertía: "quien se resiste al obispo, se resiste a los planes de Dios, ya que la autoridad eclesiástica está respondiendo a los designios del Espíritu Santo". ${ }^{73}$

\footnotetext{
${ }^{68}$ Sobre el rol de este dirigente remitimos a Camaño Semprini, Peronismo y poder municipal..., pp. 68-70.

${ }^{69}$ Justicia, 03/09/1948; Departamento Ejecutivo. 1948. Caja 2.

${ }^{70}$ Archivo Histórico San Francisco Solano. Caja 109.

${ }^{71}$ Archivo Histórico San Francisco Solano. Caja 109.

${ }^{72}$ Archivo Histórico San Francisco Solano. Caja 94. Decreto episcopal 19/01/1949.

${ }^{73}$ La Voz de Río Cuarto, 26/04/1949.
} 


\section{Hacia la ruptura con el peronismo}

El período abierto por la gestión de Bildósola se caracterizaría por una convivencia pacífica entre representantes católicos y el gobierno municipal, pero sin mayores muestras de cercanía que las que imponía el protocolo: aunque asistían conjuntamente a eventos oficiales, ya no hubo participación eclesiástica en actos con tinte partidario ni discursos de funcionarios cargados de un efusivo catolicismo. Encontramos, sin embargo, una excepción notable: a partir de 1951 se incorporó a los festejos del $1^{\circ}$ de mayo la celebración de una misa de campaña en la iglesia catedral, componente religioso que había estado ausente en las celebraciones anteriores a la fecha. ${ }^{74}$ Esta innovación no pasó desapercibida para la prensa local, que remarcó: "este año la celebración del Día de los Trabajadores tuvo, en nuestra ciudad, un ambiente muy distinto a los anteriores, pues los actos tuvieron un doble aspecto gremial y religioso". La misa estuvo a cargo de Geuna, quien manifestó que, a diferencia del pasado, "es ahora cada Primero de Mayo, día que concita a la masa proletaria del país a exteriorizar su bienestar en las calles y en las plazas de toda la República". ${ }^{75}$

Esta constituía una manifestación de apoyo explícito al gobierno nacional, lo que resulta comprensible si atendemos al momento político que se estaba viviendo. Aunque entonces todavía se presumía que los comicios se celebrarían al año siguiente, ya se respiraba un ambiente electoral. Desde marzo comenzaron a circular algunas versiones de que podrían producirse recambios en las administraciones comunales y departamentales. Tal como ya señalamos, esto implicaba -merced a la visible trabazón entre partido y Estado- que los posicionamientos en el seno del peronismo tuvieran una traducción casi inmediata en las estructuras de poder locales. Durante meses se debatieron varias cuestiones atinentes al futuro político: si los próximos candidatos a la gobernación serían militares o civiles, si se sostendría a los legisladores nacionales durante un nuevo período o, por el contrario, se apostaría por una renovación de los ocupantes de las bancas.

Otra duda persistente era si habría o no llamado a elecciones municipales en la provincia. Cuando la sanción de una nueva Ley Orgánica de Municipalidades dejara zanjados los impedimentos que hasta entonces se habían alegado para postergar estos comicios, reanudarían las especulaciones respecto a quiénes serían los candidatos del peronismo y si existía la posibilidad de que retornaran al Palacio de Mójica ${ }^{76}$ sectores otrora desplazados. Al respecto, en el mes de julio, el diario El Pueblo hizo hincapié en la visita, después de mucho

\footnotetext{
${ }^{74}$ Camaño, El uso público...p. 51.

${ }^{75}$ La Voz de Río Cuarto, 03/05/1951.

${ }^{76}$ Nombre con el que se conoce al edificio que alberga al Poder Ejecutivo municipal, por haber sido construido durante la década del treinta bajo la gestión del intendente Vicente Mójica como parte de su plan urbanístico.
} 
tiempo, de Gómez del Junco a la municipalidad: “antigua 'querencia' que, según se viene comentando, figura entre las aspiraciones irredentistas de dicho legislador y del grupo partidario que le acompaña"77; expectativas que esperaban ver favorecidas por el reciente arribo de un nuevo interventor partidario. ${ }^{78}$

Igualmente, se llegó a especular con que el senador nacional encabezara la fórmula peronista para la gobernación provincial, anhelo que luego se vería reducido a que un lugarteniente suyo fuera candidato a vicegobernador ${ }^{79} \mathrm{~A}$ mediados de septiembre se vaticinaba también que varias figuras del nacionalismo local, "altamente representativas del peronismo de la primera hora", integrarían la lista de candidatos a legisladores nacionales y provinciales. ${ }^{80}$ Llamativamente, estas especulaciones coincidieron con una visita de Buteler al presidente Perón con el objetivo de presentarle "una serie de asuntos relacionados con la marcha de la diócesis del sur de Córdoba". ${ }^{81}$

Sin embargo, este cúmulo de expectativas se vio frustrado. Dicho revés a los sectores nacionalistas coincidía con la finalización del mandato de Gómez del Junco como senador nacional, lo que supuso una ausencia desde 1952 de representantes del peronismo local en el Congreso a la vez que significó una desestabilización de las relaciones entre autoridades partidarias y dirigentes locales, en detrimento de estos últimos. Si en el mediano plazo esto facilitó la consolidación de una organización centralizada del partido y la progresiva disolución de los espacios de micropoder constituidos en torno a dirigentes parlamentarios característicos de los años previos, en el corto plazo desembocó en la renuncia de Torres Fotheringham al Partido Peronista. Aunque sin difundir el contenido de la misiva, la prensa local consideró que la nota dirigida al propio presidente del Consejo Superior fue "concebida en términos tales que superaría a todo cuanto se haya dicho hasta la fecha como disconformidad y repudio a la política imperante en las altas directivas del peronismo". ${ }^{82} \mathrm{Su}$ declinación, empero, no sería aceptada formalmente hasta 1955, cuando la ruptura entre la Iglesia católica y el peronismo fuera ya un hecho consumado. ${ }^{83}$

En efecto, para entonces ya había acontecido el festejo del 17 de octubre en los que Perón acusó a la Acción Católica de actuar con fines diferentes a aquellos por los que se había

\footnotetext{
${ }^{77}$ El Pueblo, 04/07/1951.

${ }^{78}$ El Pueblo, 03/06/1951.

${ }^{79}$ El Pueblo, 29/08/1951.

${ }^{80}$ El Pueblo, 14/09/1951; 20/09/1951.

${ }^{81}$ La Voz de Río Cuarto, 21/07/1951.

${ }^{82}$ El Pueblo, 19/10/1951.

${ }^{83}$ El Pueblo, 14/09/1951; 20/09/1951; 04/10/1951; 19/10/1951.
} 
fundado; lo cual la convertía a los ojos del gobierno en una "asociación ilícita" ${ }^{84}$ Se había efectuado también la reunión entre Perón y los gobernadores en la que, citando nombres y hechos, el presidente denunció las irregularidades cometidas por los sacerdotes que, conjuntamente con los políticos desplazados, deseaban gravitar sobre ciertos sectores de la ciudadanía para crear un clima de violencia en el país. Parecía -según afirmaba- que habían "elegido otros lugares para preparar esta misma revolución con la que vienen soñando desde hace diez años". 85

De modo que en noviembre de 1954, Monseñor Ambrosio López, asesor de la Junta Diocesana de Río Cuarto, emitió un comunicado en el que aseguraba que la Acción Católica de su jurisdicción nunca se había apartado de sus finalidades estatutarias, a saber: afirmar, actuar y defender los principios católicos en la vida individual, familiar y social. Sin embargo, sugestivamente finalizaba su mensaje con un llamado a los católicos riocuartenses "a cumplir con el deber de su bautismo de alistarse en las filas del apostolado activo". ${ }^{86}$

No obstante, el 25 de noviembre Perón nuevamente expresó su recelo ante la “infiltración clerical" en el ámbito provincial: "la palabra del gobernador fue total y confirmatoria (...) la Justicia de Córdoba estaba total y absolutamente copada por elementos clericales (...) la Universidad de Córdoba estaba en manos de elementos clericales". ${ }^{87} \mathrm{El}$ gobierno se dispuso, entonces, a neutralizar rápidamente lo que identificaba como un foco de perturbación política. Consecuentemente, aquel mismo mes el Ejecutivo nacional intervino el Poder Judicial, la Universidad Nacional de Córdoba, la Escuela Normal Superior y la Dirección General de Enseñanza Primaria. ${ }^{88}$

Asimismo, la mirada requisitoria se dirigió hacia el propio interior del peronismo. De manera que las autoridades de la Intervención del Partido Peronista del distrito Córdoba emitieron un comunicado en el que instaban a los afiliados a denunciar "a cualquier persona o entidad que por su conducta se convierta en un motivo de perturbación" y a "vigilar las actividades de todos aquellos elementos clericales que por su posición notoriamente agresiva aparezcan como enemigos y en particular, a los afiliados a nuestro partido". 89

Meses más tarde, tal como ocurrió en múltiples puntos del país, las celebraciones de Semana Santa se constituyeron en Río Cuarto en una atmósfera para la manifestación del

\footnotetext{
${ }^{84}$ La Nación, 18/10/1954, citado en Bianchi, Catolicismo y peronismo..., p. 292.

${ }^{85}$ El Pueblo, 11/11/1954.

${ }^{86}$ El Pueblo, 13/11/1954.

${ }^{87}$ Los Principios, 26/11/1954.

${ }^{88}$ Tcach, Sabattinismo y peronismo..., p. 330.

${ }^{89}$ La Calle, 23/11/1954.
} 
fervor católico y la ofensiva de la Iglesia contra el gobierno peronista. ${ }^{90}$ Tras destacar la notable concurrencia, las crónicas periodísticas reproducían algunas de las consignas enarboladas por los católicos riocuartenses: “durante las procesiones permitidas para visitar los templos, como refiriéndose a una 'Argentina enferma', el sacerdote que las acompañaba hacía entonar a los fieles el siguiente estribillo: 'La mejor penicilina, Cristo Rey a la Argentina" (...) junto con otro que decía 'Uno, dos, tres, cuatro, Cristo Rey para rato"”.91

Fue a partir de los festejos por el $1^{\circ}$ de Mayo que la tensión se acentuó para terminar virando, en las semanas sucesivas, hacia la violencia. Días después de que el secretario general de la CGT comunicara que impulsarían una reforma constitucional para establecer la separación de la Iglesia y el Estado, y de que fueran derogadas las leyes de enseñanza religiosa y de exención impositiva de que gozaban las instituciones religiosas católicas, ${ }^{92}$ el presbítero Geuna negó la existencia de los propugnados "conflictos con el clero" a través de un recorrido por las amistosas relaciones que había mantenido la Iglesia con el peronismo. Se retrotrajo, incluso, a antes de su llegada al poder para destacar la importancia del voto de los católicos en las elecciones de febrero de 1946, y afirmó que si ahora se sentían consternados no era por ningún conflicto preexistente, "sino simplemente porque sienten turbada su conciencia con medidas y leyes que atentan directamente contra sus más profundas y arraigadas convicciones católicas". ${ }^{93}$ En respuesta a estas observaciones que se divulgaron a través de las páginas de la prensa opositora y de la distribución de panfletos por parte de otro sacerdote local, Carmelo Bruno, el Sub Comando Táctico del Movimiento Peronista emitió un comunicado en el que los homologaba con la "antipatria". 94

Esta identificación señalada por el oficialismo, de los sectores clericales con los partidos opositores, y de ambos, con la "oligarquía" y los intereses extranjeros, se recrudeció a partir de junio, cuando la violencia política simbólica dio paso a la física. Previamente, avanzado el mes de mayo se había desencadenando una serie de episodios que fueron enrareciendo el clima político local. El tradicional Te Deum en la catedral con motivo del aniversario de la Revolución de Mayo no contó, en aquella circunstancia, con la acostumbrada presencia de las autoridades civiles y militares. En un templo -según las crónicas- "atestado de fieles" y desbordado en su capacidad, Geuna ocupó el púlpito para pronunciar una oración cívico-religiosa que giró en torno a dos temas fundamentales: "que la esencia del cristianismo

\footnotetext{
${ }^{90}$ Bianchi, Catolicismo y peronismo..., pp. 305-307.

${ }^{91}$ El Pueblo, 09/04/1955.

${ }^{92}$ Bianchi, Catolicismo y peronismo..., pp. 305-307.

${ }^{93}$ El Pueblo, 10/05/1955.

${ }^{94}$ El Pueblo, 18/05/1955.
} 
[era] la libertad y dignidad humana, teniendo como base la verdad" y que, contrariamente a lo que algunos habían pretendido sostener, la Iglesia católica no era una organización política internacional sino "profundamente patriótica" y "respetuosa de los poderes constituidos". Cerró con una plegaria por la paz, la armonía y el progreso de la Nación y por la libertad y el bienestar del pueblo. Sugerentemente, sus preces terminaron con las estrofas finales del himno nacional: "Coronados de gloria vivamos o juremos con gloria morir!". 95

Al finalizar el Te Deum, los asistentes se retiraron de la catedral entonando canciones religiosas y dando vivas a la patria. Algunos de ellos improvisaron una manifestación por las calles circundantes a la plaza Roca que culminaría con la intervención policial y la detención de ocho personas, entre ellos dirigentes de la Unión Cívica Radical y el Partido Demócrata. Según versiones recogidas por la prensa local, Buteler se encontraba en la portada de la catedral al momento de producirse los hechos, y ante el requerimiento de la policía para que ordenara a los manifestantes habría contestado que su autoridad era "de puertas para adentro". Posteriormente, el obispo y las jerarquías de la Acción Católica local elevaron telegramas al ministro de gobierno de la provincia, el riocuartense Ricardo Obregón Cano, para reclamar por la libertad de los detenidos. ${ }^{96}$

Días más tarde, la celebración del Corpus Christi en Buenos Aires se constituyó en una explícita manifestación antigubernamental que excedía las autoridades eclesiásticas, pues al finalizar el rito, una nutrida columna enfiló por la Avenida de Mayo en dirección al Congreso. En el camino, los manifestantes apedrearon las sedes de los diarios oficialistas, destrozaron los vidrios de los edificios públicos, pintaron con alquitrán las consignas "Muera Perón" y "Viva Cristo Rey"; y al llegar a la sede del Poder Legislativo, quitaron una placa en homenaje a Eva Perón y arriaron la enseña nacional para enarbolar la bandera papal. ${ }^{97}$

Frente a estos hechos y a la responsabilidad que el gobierno hizo recaer sobre "reaccionarios clericales y políticos de la vieja oligarquía que no se resignan a su desplazamiento de la vida ciudadana", ${ }^{98}$ la Junta Diocesana de la Acción Católica de Río Cuarto emitió un comunicado en el que reiteraba "su inquebrantable fe argentinista" y proclamaba "su condenación ante el agravio inferido a la Bandera de la Patria", al tiempo que invitaba "a todos los asociados a elevar fervientes plegarias a Dios Nuestro Señor por los destinos de la Nación y sus instituciones, por la Iglesia y su jerarquía". ${ }^{99}$ Ese mismo día, tal

\footnotetext{
${ }^{95}$ El Pueblo, 27/05/1955.

${ }^{96}$ El Pueblo, 27/05/1955.

${ }^{97}$ Bianchi, Catolicismo y peronismo..., pp.307-308.

${ }^{98}$ El Pueblo, 14/06/1955.

${ }^{99}$ El Pueblo, 16/06/1955.
} 
como ocurría en todo el país, y mientras la plaza de mayo era bombardeada, la sede fue clausurada. Pese a esto, desde el Obispado se hizo público que "los organismos Diocesanos de la Acción Católica en Río Cuarto continuar[ían] sus actividades de apostolado" ${ }^{100}$

En las semanas posteriores, los llamados conciliatorios del gobierno recibieron como respuesta la movilización. En esta dirección, florecían públicamente agrupaciones que nucleaban a profesionales y estudiantes católicos, algunas ya existentes, otras nacidas al calor del enfrentamiento con el peronismo. Asimismo, fue creado el Instituto Superior de Cultura Religiosa de Río Cuarto, orientado a la formación intelectual y moral de los profesores de religión y se duplicaron los actos públicos de piedad, como el rezo del rosario. ${ }^{101}$

Además de estas disputas simbólicas, también iban en aumento los episodios de hostilidad y violencia. Así, a comienzos de septiembre, fueron atacados con armas de fuego dirigentes de la Acción Católica local. ${ }^{102} \mathrm{El}$ agravio se produjo en un clima de profundización de las conflagraciones, tras el virulento discurso pronunciado por Perón el 31 de agosto, en el que instaba a los peronistas a "contestar a una acción violenta con otra más violenta. Y cuando uno de los nuestros caiga, caerán cinco de los de ellos". ${ }^{103}$ Si hasta el momento la atmósfera de tácita complicidad entre radicales y católicos no se había traducido en frentes, coaliciones o acuerdos de índole orgánica, a partir de entonces, fue prácticamente unánime el acuerdo de la oposición política en torno a la conveniencia de un golpe o movimiento cívicomilitar. $^{104}$

\section{Desde un lugar de la patria...}

El comando de la IV Región Militar con sede en Río Cuarto se constituyó en punta de lanza del levantamiento bajo la dirección del general Dalmiro Videla Balaguer. Sus buenas relaciones con los conspiradores civiles confluyeron en un clima caldeado por la participación del caudillo unionista Miguel Ángel Zavala Ortiz en los bombardeos del 16 de junio y la pronta constitución de comandos civiles por otros dirigentes radicales como Conrado Storani, Fernando Mauhum, Enrique San Millán, Antonio Subirachs y Enrique Bauducco. ${ }^{105}$

\footnotetext{
${ }^{100}$ El Pueblo, 17/10/1955.

${ }^{101}$ REAC, SDRC, 1955, pp. 340-342.

${ }^{102}$ El Pueblo, 04/09/1955.

${ }^{103}$ El Pueblo, 01/09/1955.

104 Tcach, Sabattinismo y peronismo..., pp. 245 y 253.

105 Tcach, Sabattinismo y peronismo..., pp. 254-254.
} 
Junto a los generales Justo León Bengoa y Pedro Eugenio Aramburu, Videla Balaguer era considerado uno de los referentes de la conspiración militar dentro del Ejército. ${ }^{106}$ Sus contactos con los civiles se dirigieron hacia dos sentidos: el sector unionista del radicalismo, y el catolicismo. Con el primero, el nexo fue su asistente en el comando, el mayor Juan Fernández Funes, novio de la hija del dirigente y ex diputado nacional Mauricio Yadarola. Con el segundo, el enlace fue el abogado Luis Guillermo Torres Fotheringham, a quien lo unía una estrecha relación personal, a punto tal que al convocarlo para que se sumara a la conspiración le formuló una singular propuesta: "Lo invito, mi doctor, a que nos hagamos matar". 107

Mientras que los comandos civiles católicos que Tristán Castellano articulaba en Córdoba prestaron una completa predisposición para iniciar el levantamiento, los sectores militares respondieron que el alzamiento se produciría siempre que fuera dirigido por el coronel Arturo Ossorio Arana. Incluso, dentro del propio comando de Videla Balaguer surgieron disidencias respecto a la conveniencia o no de iniciar las acciones. Finalmente, se resolvió esperar hasta el 2 de septiembre para garantizar la presencia en Córdoba de Ossorio Arana, el militar deseado por los oficiales de Artillería. ${ }^{108}$

Sin embargo, cuando el 1 de septiembre Ossorio Arana se hizo presente en Córdoba, estuvo más dispuesto a informarse sobre el terreno que a operar de inmediato, por lo que al atardecer el comando militar de Río Cuarto recibió un llamado telefónico que informaba "No hay negocio". La traición de uno de los juramentados forzó a la desaparición de todos los jefes militares del comando y su ocultamiento en distintos lugares cedidos por los miembros de los comandos civiles de la ciudad. En estas circunstancias, el 4 de septiembre lanzó "desde algún lugar de la patria" una proclama que fue transmitida por una emisora radiofónica clandestina del comando civil católico. ${ }^{109}$ Entre otras afirmaciones, en ella declaraba: "Dios y la Patria esperan confiados en la decisión y el valor, jamás desmentidos de los argentinos, que escribirán así, una de las páginas más gloriosas de nuestra historia (...) La limpia y heroica tradición argentina patriótica, y Dios y la Patria nos darán fuerza y coraje para vencer tanta humillación y flaqueza (...) Arriba los corazones, que la Virgen Generala nos protege". ${ }^{110}$

Dada la importancia de la IV Región Militar, el gobierno intentó evitar los efectos multiplicadores que su rebelión podía llegar a generar. Por ello, recurrió a un silencio absoluto

\footnotetext{
106 María Estela Spinelli, Los vencedores vencidos. El antiperonismo y la "revolución libertadora" (Buenos Aires: Biblos, 2005), p. 49.

107 Tcach, Sabattinismo y peronismo..., pp. 254-255.

108 Tcach, Sabattinismo y peronismo..., p. 255.

109 Tcach, Sabattinismo y peronismo..., pp. 255-256.

${ }^{110}$ Los Principios, 13/10/1955.
} 
que exasperaba a los sublevados: de no propagarse los focos rebeldes, su detención era inminente. Consecuentemente, Videla Balaguer confió al dirigente radical Norberto Spertino la tarea de trasladarse a Buenos Aires para pedirle a Yadarola que hiciese transmitir por radios de Uruguay y Chile que no se encontraban presos, como era creencia generalizada. Yadarola decidió entonces pedir un informe a la Cámara de Diputados, en el que preguntaba si era exacto que el gobierno había descubierto una sublevación militar en Río Cuarto y, si era así, por qué se la mantenía en secreto mientras se apresuraba a publicitar los complots atribuidos a civiles, que servían de pretexto para encarcelar a hombres libres. El movimiento de Yadarola dio los resultados esperados: el gobierno nacional hizo pública la requisitoria del juez militar de Río Cuarto. Como se había previsto, al poner en evidencia el estado de sublevación en el sur cordobés, su efecto inmediato fue enhebrar las conspiraciones en curso que, coordinando su accionar, derrumbarían al gobierno peronista semanas más tarde. ${ }^{111}$

Aunque el escenario principal de las acciones fue la ciudad de Córdoba, resultó protagónico el rol de los riocuartenses que -en tanto integrantes de los comandos civiles"cumplieron misiones de enlace, ocultamiento o de combate". ${ }^{112}$ En efecto, fueron quienes ayudaron a escapar a Videla Balaguer disfrazado de "pacífico sacerdote" hacia Córdoba, ciudad a la que arribaría el 13 de septiembre, escondido en el baúl de un automóvil. ${ }^{113}$ Junto a otros conspiradores, fue hospedado en la casa de quien actuaba como nexo con los que encabezarían las operaciones militares: Tristán Castellano. Fue en este domicilio donde -de acuerdo con relatos posteriores- juraron "lealtad a la Revolución, sobre las Sagradas Escrituras". ${ }^{114}$ Cuando días más tarde se produjo el levantamiento con el lema "Por Dios y la Patria" y la seña "Dios es justo", la casa de Castellano sería rodeada por un cerco policial; disipado horas después por la acción conjunta de comandos civiles de Alta Córdoba y una patrulla de la Aeronáutica que "rescataron" a Videla Balaguer, quien debía dirigir las operaciones en la ciudad: "La empresa no iba a ser fácil. Se produjo un intenso tiroteo, mientras dos aviones comenzaron a accionar sobre el lugar, para favorecer la retirada del jefe buscado. En una acción de una audacia sin límites, el general Videla fue puesto a salvo y se esfumó en las propias barbas de la Policía, juntamente con sus defensores". ${ }^{115}$

\footnotetext{
111 Tcach, Sabattinismo y peronismo..., pp. 256-257.

112 Dalmiro Videla Balaguer, en carta personal del 26/09/1989. Citado en Griselda Pécora, Río Cuarto y su papel protagónico en la revolución de septiembre de 1955. Trabajo Final de Licenciatura en Historia (Río Cuarto: Departamento de Historia, Facultad de Ciencias Humanas de la Universidad Nacional de Río Cuarto, 1989), p. 45.

${ }^{113}$ Los Principios, 16/09/1956. También ver: Pécora,Río Cuarto y su papel protagónico..., p. 21.

${ }^{114}$ Marta Lonardi, Mi padre y la Revolución del 55 (Buenos Aires: Cuenca del Plata, 1980), p. 85.

${ }^{115}$ Los Principios, 16/09/1956.
} 
Efectivamente, esta fue una de las acciones clave que permitió que, desde el anochecer del 16 de septiembre, el gobierno nacional comenzara a ejercerse en manos de un "comando revolucionario" presidido por Lonardi bajo la advocación de la Virgen María e integrado casi en su totalidad por los sublevados de Río Cuarto. ${ }^{116}$ Durante esos últimos meses, la dinámica política provincial estuvo signada por el nacimiento de un nuevo mito -el de "Córdoba la heroica", "cuna de la libertad", "bastión de la fe"- fundado sobre el protagonismo de los civiles en el levantamiento armado, y cuya primera consecuencia se materializaría en las designaciones del general Videla Balaguer como gobernador de Córdoba y de Tristán Castellano como intendente de la ciudad. ${ }^{117}$

\section{Consideraciones finales}

A la pequeña e histórica ciudad mediterránea de Río Cuarto, antigua línea divisoria entre la civilización y la barbarie, le ha cabido en la hora sombría que vivía la República, el inmenso honor de haber lanzado el chispazo luminoso que, extendiéndose por todos los ámbitos, ha iluminado las conciencias y despertado el alma dormida de la argentinidad. ${ }^{118}$

Estas palabras, pronunciadas por Luis Guillermo Torres Fotheringham en octubre de 1955 en las radios locales, y luego reproducidas en el diario católico de tirada provincial Los Principios, se pueden interpretar como una síntesis de una lectura compartida por el segmento político analizado, tanto de la historia nacional y riocuartense como del modelo de sociedad deseado, en el que no eran ajenas las pretensiones de un mantenimiento -bajo un tono antiplebeyo y un mentado apoliticismo- de las jerarquías y distinciones sociales.

Puntualmente, nuestro propósito fue reconstruir y analizar el devenir de diversos actores vinculados a los abigarrados mundos del nacionalismo, el catolicismo y el espectro partidario de Río Cuarto que -articulados por su confluencia en diversos ámbitos de participación en la esfera pública- influyeron e incluso definieron la vida política local, atravesando gobiernos de diversas tendencias. Como pudimos observar, los confines de estos nexos fueron ambiguos y los acercamientos tuvieron movimientos pendulares en virtud del

\footnotetext{
${ }^{116}$ Formaban parte de este comando revolucionario los coroneles Juan Bautista Picca y Raúl Picasso, el teniente coronel Carlos Carabba, el mayor Jorge Manuel Fernández Funes. El único externo al grupo riocuartense era el comandante Eduardo Arenas, en representación de la Aeronáutica.

${ }_{117}$ César Tcach, De la Revolución Libertadora al Cordobazo. Córdoba, el rostro anticipado del país (Buenos Aires: Siglo XXI, 2012), p. 20.

${ }^{118}$ Los Principios, 13/10/1955.
} 
impulso dado, en ocasiones, por la conveniencia estratégica $y$, en otras tantas, por coincidencias ideológicas más profundas; situación que se vio complejizada aún más por la pluralidad de voces que habitaba en su propio interior y las disputas que los atravesaban.

Por momentos, el acceso al poder efectivo les resultó escurridizo, en otras instancias en cambio integraron el aparato estatal e impulsaron políticas concretas, o bien encabezaron estrategias opositoras frente a quienes dirigían los destinos públicos, ya sea al interior del propio oficialismo del que formaban parte como desde la disidencia, con maniobras que tendían a alejarse de las reglas del juego democrático y que tornaban en espejismo al mentado apoliticismo sostenido discursivamente.

Durante los años sabattinistas, el progresivo estrechamiento de los lazos entre sectores del catolicismo, elementos vinculados a la derecha y miembros del Ejército -ya manifiesto durante los gobiernos conservadores- adquirió nuevos matices por el común enfrentamiento a sus políticas gubernamentales, consideradas antesalas del comunismo y del caos social. Así, esta trama nos permitió explicar también el temprano apoyo dado al gobierno militar surgido del golpe de Estado de 1943 y el fortalecimiento a partir de entonces de la ligazón entre sectores católicos y un ala del radicalismo, que luego desembocaría en el naciente peronismo y desempeñaría un rol clave en su triunfo en 1946.

El hecho de que el eje articulador de dichos nexos hayan sido exponentes del nacionalismo influyó notablemente en las relaciones entre los gobiernos locales y las jerarquías eclesiásticas, afectadas también por la cuestión municipal. Si hasta 1951 la ausencia de elecciones comunales implicó que las disputas, alianzas y posicionamientos al interior del partido tuvieran un impacto sensible en la estructura de los poderes públicos locales -claro ejemplo de ello fue el periodo durante el cual el gobierno municipal estuvo a cargo del Comisionado Nolasco Ferreyra-, su convocatoria en aquel año abrió expectativas para los nacionalistas que se vieron a la postre frustradas, lo cual llevó a que Torres Fotheringham renunciara al Partido Peronista.

No resulta casual que su declinación fuera aceptada recién en 1955, cuando la mirada requisitoria se había dirigido hacia el interior del peronismo en busca de infiltrados clericales -entre quienes se encontraban muchos de los nombres recurrentes a lo largo de nuestra investigación-, y poco antes de que la participación activa de estos sectores coadyuvara a la caída del gobierno peronista; coyuntura en que emergieron públicamente aquellos nexos que vislumbramos a lo largo de todo el período analizado.

Para finalizar, consideramos que este recorrido nos ha permitido captar la porosidad y complejidad de los vínculos e intersecciones entre lo político y lo religioso, cuyas 
convergencias - tanto en el plano estratégico como en el simbólico- se daban en torno a una mirada común acerca del pasado, del orden deseable y de los medios para construirlo; al tiempo que deja abierto el interrogante sobre su pervivencia en la vida política, incluso hasta la actualidad.

\section{Referencias bibliográficas}

Barbero, María Inés y Devoto, Fernando. Los nacionalistas. Buenos Aires: CEDAL, 1983.

Barletta, María y Béjar, María Dolores. "Nacionalismo, nacionalismos, nacionalistas... ¿Un debate historiográfico?”. Anuario IEHS, 3 (1988): 357-383.

Bianchi, Susana. Catolicismo y peronismo. Religión y política en la Argentina 1943-1955. Tandil: Trama/Prometeo/Instituto de Estudios Histórico-Sociales, 2001.

Bisso, Andrés. Acción Argentina. Un antifascismo nacional en tiempos de guerra mundial. Buenos Aires: Prometeo, 2005.

Blanco, Jessica. Modernidad conservadora y cultura política. La Acción Católica Argentina (1931-1941). Córdoba: Facultad de Filosofía y Humanidades de la Universidad Nacional de Córdoba, 2008.

Buchrucker, Cristián. Nacionalismo y peronismo. La Argentina en la crisis ideológica mundial (1927-1955). Buenos Aires: Sudamericana, 1987.

Caimari, Lila. Perón y la Iglesia católica. Religión, Estado y sociedad en la Argentina (19431955). Buenos Aires: Emecé, 2010 [1994].

Camaño Semprini, Rebeca. 'De 'reinado sabio' a 'tiranía': el peronismo desde la mirada de Monseñor Leopoldo Buteler (Río Cuarto, 1945-1955). Coordenadas. Revista de Historia Local y Regional 7, 1 (2020): 61-84.

. "Ecos de la Guerra Civil Española. La derecha nacionalista y los frentes antifascistas en los espacios locales argentinos". Diacronie Studi di Storia Contemporanea, 17 (2014):1-15.

- "Laicos y políticos: la Acción Católica en la vida partidaria riocuartense (19361946)". Revista de Historia Americana y Argentina, 53 (2018): 67-97.

. Peronismo y poder municipal. De los orígenes al gobierno en Río Cuarto (Córdoba, 1943-1955). Rosario: Prohistoria, 2014.

Camaño, Rebeca. "El radicalismo riocuartense: renovación partidaria, conservadores y fascismo en los años treinta". Estudios Sociales, 49 (2015): 11-30. 
. El uso público del tiempo libre de los trabajadores riocuartenses (1945-1955).

Trabajo Final de Licenciatura en Historia. Río Cuarto: Departamento de Historia,

Facultad de Ciencias Humanas de la Universidad Nacional de Río Cuarto, 2011.

Cersósimo, Facundo. "El tradicionalismo católico argentino: entre las Fuerzas Armadas, la Iglesia católica y los nacionalismos". PolHis 7, 14 (2014): 341-374.

Cucchetti, Humberto. "Lecturas e interpretaciones sobre los orígenes del peronismo:

¿nacional-populismo o adaptación fascista?”. Studia Historica. Historia

Contemporánea, 30 (2012): 151-171.

[http://campus.usal.es/ revistas_trabajo/index.php/0213-2087/article/view/9903].

Devoto, Fernando. Nacionalismo, fascismo y tradicionalismo en la Argentina moderna. Una historia. Buenos Aires: Siglo XXI, 2002.

Di Stefano, Roberto y Zanca, José. "Iglesia y catolicismo en Argentina. Medio siglo de historiografía". Anuario de Historia de la Iglesia, 24 (2015): 15-45. [10.15581/007.24.15-45].

Di Stefano, Roberto. "De la teología a la historia: un siglo de lecturas retrospectivas del catolicismo argentino". Prohistoria 6, 6 (2002): 173-201.

Echeverría, Olga. “¿Las cosas por su nombre? Preguntas sobre la propensión a llamar 'nacionalismo' a la derecha argentina de la década de 1920”, en Las derechas en el Cono Sur, Siglo XX. Actas del Taller de discusión, compilado por Ernesto Bohoslavsky. Los Polvorines: Universidad Nacional de General Sarmiento, 2011.

. Las voces del miedo: los intelectuales autoritarios argentinos en las primeras décadas del siglo XX. Rosario: Prohistoria, 2009.

Fichelstein, Fernando. La Argentina fascista. Los orígenes ideológicos de la dictadura. Buenos Aires: Sudamericana, 2008.

Gómez del Junco, Felipe. El Perón que yo conocí. Buenos Aires: edición del autor, 1982.

Lida, Miranda. "Catolicismo y peronismo: la zona gris”. Ecos de la Historia, 6 (2010):10-13. . "El catolicismo de masas en la década de 1930. Un debate historiográfico", en Sociedad, cristianismo y política. Tejiendo historias locales, compilado por Cinthya Folquer y Sara Amenta. San Miguel de Tucumán: Universidad del Norte Santo Tomás de Aquino, 2010.

. Historia del catolicismo en la Argentina entre el siglo XIX y el XX. Buenos Aires: Siglo XXI, 2015.

Lonardi, Marta. Mi padre y la Revolución del 55. Buenos Aires: Cuenca del Plata, 1980. 
Macor, Darío y Tcach, César. "El oxímoron peronista en las provincias" en La invención del peronismo en el interior del país II, editado por Darío Macor y César Tcach. Santa Fe: Universidad Nacional de Litoral, 2013.

Mallimaci, Fortunato, Cucchetti, Humberto y Donatello, Luis. "Caminos sinuosos: nacionalismo y catolicismo en la Argentina contemporánea”, en El altar y el trono. Ensayos sobre el catolicismo político latinoamericano, editado por Francisco Colom y Ángel Rivero. Barcelona: Antrophos/Unilibros, 2006.

Mallimaci, Fortunato. El catolicismo integral en la Argentina (1930-1946). Buenos Aires: Biblos, 1988.

. El mito de la Argentina laica. Catolicismo, política y Estado. Buenos Aires: Capital Intelectual, 2015.

McGee Deutsch, Sandra. Countrrevolution in Argentina, 1900-1932: the argentine Patriotic League. Lincoln: University of Nebraska, 1986.

Navarro Gerassi, Marysa. Los nacionalistas. Buenos Aires: Jorge Álvarez, 1969.

Orbe, Patricia. "El nacionalismo tradicionalista argentino en la segunda mitad del siglo XX: recorrida por un territorio en exploración”. PolHis 8, (2011): 27-35.

Panebianco, Angelo. Modelos de partido. Organización y poder en los partidos políticos. Madrid: Alianza, 1990 [1982].

Rock, David. La Argentina autoritaria. Los nacionalistas, su historia y su influencia en la vida pública. Buenos Aires: Ariel, 1993.

Spinelli, María Estela. Los vencedores vencidos. El antiperonismo y la "revolución libertadora”. Buenos Aires: Biblos, 2005.

Tato, María Inés. "El ejemplo alemán. La prensa nacionalista y el Tercer Reich". Revista Escuela de Historia, 6 (2007): 34-60. . “AAlianzas estratégicas o confluencias ideológicas? Conservadores y nacionalistas en la Argentina de los años treinta”. Cuadernos del CLAEH 28, 91 (2005): 119-135.

Tcach, César. Sabattinismo y peronismo. Partidos políticos en Córdoba (1943-1955). Buenos Aires: Biblos, 2006 [1991].

. "Entre la tradición conservadora y la tentación fascista: la derecha cordobesa contra Amadeo Sabattini", XII Jornadas Interescuelas/Departamentos de Historia. San Miguel de Tucumán: Universidad Nacional de Tucumán, 2007.

. "Un parto frustrado: la intervención federal a Córdoba (1936-37)”, en Territorios de la política argentina. Córdoba y Santa Fe. 1930-1945, editado por Darío Macor y Susana Piazzesi. Santa Fe: Universidad Nacional del Litoral, 2009. 
De la Revolución Libertadora al Cordobazo. Córdoba, el rostro anticipado del país. Buenos Aires: Siglo XXI, 2012.

- "Entre la benevolencia y la sospecha: los actores políticos de Córdoba ante el golpe de 1943 y el fin de la experiencia sabattinista”. Avances del Cesor 12, 13 (2015): 35-48.

Zanatta, Loris. Del Estado liberal a la Nación católica. Iglesia y Ejército en los orígenes del peronismo.1930-1943. Bernal: Universidad Nacional de Quilmes, 2005 [1996]. Perón y el mito de la nación católica. Iglesia y Ejército en los orígenes del peronismo (1943-1946). Buenos Aires: Sudamericana, 1999.

Zuleta Álvarez, Enrique. El nacionalismo argentino. Buenos Aires: La Bastilla, 1975. 